\title{
Management of Perianal Fistulas in Crohn's Disease
}

\author{
Steffen Seyfried ${ }^{\mathrm{a}} \quad$ Alexander Herold $^{\mathrm{b}}$ \\ ${ }^{a}$ Department of Surgery, Universitätsmedizin Mannheim, Medical Faculty Mannheim, Heidelberg University,

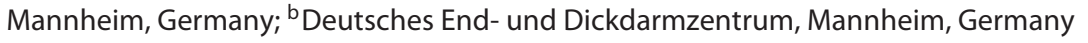

\section{Keywords}

Inflammatory bowel disease - Fistula Stem cell · TNF-a · Sphincter reconstruction

\section{Abstract}

Background: Perianal fistulizing Crohn's disease is associated with severe symptoms such as pain, fecal incontinence, and a significant reduction in quality of life. Results: In refractory cases, many patients face the decision of having a stoma and/or requiring proctectomy. In former years, the standard of care was a complete fistulectomy, bringing with it a high rate of continence disorders. Additionally, many patients received indefinite treatment, namely the placement of a seton to maintain surgical drainage. Conclusion: More recently, newer biologics, cell-based therapies as well as novel surgical techniques have been introduced, raising new hopes that outcomes can be improved upon.

(c) 2019 S. Karger AG, Base

\section{Introduction}

Perianal fistulation is common in patients with Crohn's disease (CD), the estimated life-time risk of perianal fistula being between 14 and $38 \%$ in population-based estimates [1]. Perianal fistulizing CD (PFCD) is associated with severe symptoms such as pain, fecal incontinence, and a significant reduction in quality of life. In refractory cases, many patients face the decision of having a stoma and/or requiring proctectomy [2]. In former years, the standard of care was a complete fistulectomy, bringing with it a high rate of continence disorders. Additionally, many patients received indefinite treatment, namely the placement of a seton to maintain surgical drainage [3].

Perianal fistulas in CD can be simple or complex, and treatment algorithms vary according to the severity of the perianal involvement and this classification [4].

More recently, newer biologics, cell-based therapies as well as novel surgical techniques have been introduced, raising new hopes that outcomes can be improved upon.

\section{Classification and Predictive Factors}

Fistulas can be discriminated into simple and complex fistulas (according to the AGA-classification). A simple fistula is a low fistula with only a single external opening and is not associated with abscess formation, rectovaginal fistula, or an anorectal stricture.

In a single-center study involving 232 patients with perianal CD longstanding remission for complex fistulas was seen in only $37 \%$ of the patients after a 10 -year followup compared to almost $67 \%$ for simple fistulas [5]. A recent systematic review concluded that a combination of medical and surgical treatment approaches is superior to either single treatment alone. The importance of a multidisciplinary patient care is highlighted by superior rates of complete remission (52\%) in the combination versus single-therapy (43\%) group [6]. An important and worrisome aspect of PFCD is the occurrence of malignant transformation of perianal fistulas. Although this event is rare, it nevertheless is of crucial importance for the affected patients $[7,8]$.

\section{KARGER}

(C) 2019 S. Karger AG, Basel
Dr. med. Steffen Seyfried

Department of Surgery, Universitätsmedizin Mannheim

Medical Faculty Mannheim, Heidelberg University

Theodor-Kutzer-Ufer 1-3, DE-68167 Mannheim (Germany)

E-Mail steffen.seyfried@umm.de 
Before thinking about therapy, we should keep in mind that fistulas rarely heal spontaneously, and surgical therapy is often necessary [9]. The data need to be interpreted carefully as the definitions of response varied, and it is difficult to ascertain what the true fistula closure rate is $[6,10]$.

\section{Antibiotics and Other Medical Agents}

Conventional agents reported to be of clinical benefit in uncontrolled trials include antibiotics and the thiopurines. They often lead to symptomatic improvement with a decrease in fistula drainage. Many of the authors, however, will use these antibiotics in combination with other therapies. There is little evidence on the use of antibiotics alone in the treatment of PFCD, with meta-analyses on the use of ciprofloxacin suggesting a marginal effect in remission [11]. In combination with adalimumab, it may offer additional benefit in healing [12]. Recent guidelines suggest that antibiotics in perianal sepsis might be of benefit only in immunosuppressed patients.

\section{Aminosalicylates}

There is no evidence for the efficacy of 5-ASA agents for the treatment of PFCD, neither for orally nor rectally applied formulations. Therefore, these agents cannot be recommended for this indication. However, there might be a role especially for rectally applied 5-ASA formulations to address clinical symptoms of active rectal inflammation [10].

\section{Anti-TNF Therapy}

The roles of anti-TNF- $\alpha$ therapy and azathioprine are well established in this setting, so their positions as drugs of choice are merited [11-15].

\section{Infliximab}

Infliximab (IFX) revealed to achieve impressively high complete (55 vs. $13 \%$ placebo) and partial (i.e., reduction of $\geq 50 \%$ of the draining fistula; 68 vs. $26 \%$ placebo) fistula closure rates [15].

The ACCENT II trial published prospective data from 304 patients with PFCD. It reported a complete healing in $36 \%$ of the IFX group and $19 \%$ of the placebo group $(p=0.0009)$ [16]. Due to the high proportion of recurrent fistulas in the follow-up study, one must assume that it is not a cure of the fistula but a lack of symptoms as long as the patients receive medication.

\section{Adalimumab}

Regarding adalimumab, there are no trials investigating fistula closure as primary endpoint.

In a subgroup analysis, the CHARM randomized trial reported a significant decrease in the number of draining fistulas per day compared with placebo in a cohort of 117 patients [17].

\section{Vedolizumab}

Up to present, there is no specific clinical trial investigating a potential effect of vedolizumab on fistula closure in CD. However, a study with fistula healing at week 30 as primary endpoint appears to be currently recruiting patients (NCT02630966).

\section{Local Treatments}

The aim of this procedure is to reduce systemic side effects and focus treatment effects on the area of interest. In addition, these treatments are typically thought to be minimally invasive and offer quick recovery times.

\section{Infliximab}

Local injection of IFX is attractive as an option to limit its systemic immunosuppressant effect. There are a few small trials that have attempted this with improvement of symptoms $[18,19]$. However, in patients who also have intestinal disease, systemic IFX would offer dual benefit and may be preferred. Surprisingly, to our knowledge, the therapy has not found its way into the daily clinical routine.

\section{Cell-Based Therapy in PFCD}

First small studies about 7 years ago using topically administered mesenchymal stem cells in fistulizing CD revealed promising results $[20,21]$. A recent study in the Netherlands with 21 refractory fistulizing CD patients investigated the effect of locally administered bone marrowderived mesenchymal stromal cells in three different dosages (groups 1-3) in a placebo-controlled, double-blind trial, with fistula healing [5]. In a phase III randomized controlled trial (RCT), 200 patients from 19 centers were randomized to receive 20 million stromal cells. While there were no significant differences in the healing rates at 24 and 52 weeks, the treatment groups had higher rates of healing than the controls, with 1-year healing rates of $57 \%$ as compared with $37 \%(p=0.13)$ [22]. Despite the promising results, this is the only higher-evidence study that supports the treatment with mesenchymal stem cell therapy.

\section{Principals and Surgical Techniques in the Treatment of Perianal Fistulas}

In acute settings, most surgeons perform conservative and sphincter-preserving procedures, in the form of drainage of sepsis and use of a draining seton [11]. The use of cutting setons is obsolete and may lead to incontinence, especially in patients with inflammatory bowel disease. Patients with PFCD tend to have a chronic and recurrent disease course necessitating multiple interventions, and therefore efforts should be made to preserve continence where possible [23]. There is a wide range of procedures offered as definitive surgical options for patients with PFCD. Draining seton alone, fistulotomy with or without reconstruction, fistula plug, video-assisted 
anal fistula treatment (VAAFT) and ligation of the intersphincteric fistula tract (LIFT) have been described in the literature, with varying outcomes $[3,11,24]$.

\section{Long-Term Seton for Complex Anal Fistulas}

Long-term indwelling seton is an effective management modality for complex perianal fistulas in $\mathrm{CD}$ and seems to decrease the need for temporary or permanent stomas. The treatment allows the induction of anti-inflammatory agents [25]. Clinical symptoms decrease, but as in conservatively and medically treated fistulas there is no definitive healing [26].

\section{Fistulectomy and Fistulotomy}

Subanodermal, submucosal, subcutaneous, distal intersphincteric, and distal transsphincteric fistulas, which affect only a small part of the sphincter muscles, can be completely cut without compromising continence. The decision on how much sphincter can be cut is influenced by the following factors: gender, previous surgeries, age, fistula localization, and preoperative sphincter function. In general, complete healing of the lesion takes 6-12 weeks, depending on the size of the wound. The recurrence rate is low (below 10\%) [27].

\section{Flap Procedures}

The advancement flap is probably the most used technique, with healing in approximately $50 \%$ of the patients. The reported data show heterogenous results and are summarized in Table 1.

\section{Ligation of the Intersphincteric Fistula Tract}

The aim of this procedure is to ligate the fistula through a perineal wound. So basically, the sphincter is not affected. There are several case series $[35,36]$ and one RCT in patients with and without CD. Primary healing rates ranged from 47 to $95 \%$. Kamiński et al. [38] looked at the long-term outcome of patients with CD undergoing LIFT and reported reduced healing rates compared with those reported previously. Whilst there was a $67 \%$ healing rate at the 12-month follow-up, the overall fistula healing rate was $48 \%$ up to 58 months. Sirany et al. [37] summarized that the true efficacy of the procedure is unknown because of the number of technical variations and the divergent results reported in the literature (Table 2).

\section{Video-Assisted Anal Fistula Treatment}

Key steps included excision of the external (perianal) opening of the fistula tract, insertion of the fistuloscope, visualization of the fistula tract and/or side tracts using the fistuloscope, and correct localization of the internal fistula opening under direct vision with irrigation. If potential side tracts were identified, fistula tissue was destroyed by using electrocautery or brushing. Schwander [40] dem-
Table 1. Results with the flap procedures

\begin{tabular}{lrrll}
\hline First author [ref.] & Year & $n$ & $\begin{array}{l}\text { Healing, } \\
\%\end{array}$ & $\begin{array}{l}\text { Recurrence, } \\
\%\end{array}$ \\
\hline Joo [28] & 1998 & 26 & 65 & 35 \\
Makowiec [29] & 1995 & 20 & 75 & 25 \\
Athanasiadis [30] & 1995 & 29 & 52 & 48 \\
Sonoda [31] & 2002 & 44 & 50 & 50 \\
Mizrahi [32] & 2002 & 28 & 57 & 43 \\
van Koperen [34] & 2009 & 9 & 45 & 55 \\
\hline
\end{tabular}

Table 2. Results with LIFT

\begin{tabular}{lcrll}
\hline First author [ref.] & Year & $n$ & $\begin{array}{l}\text { Healing, } \\
\%\end{array}$ & $\begin{array}{l}\text { Recurrence, } \\
\%\end{array}$ \\
\hline Abcarian [35] & 2014 & 1 & - & - \\
Ellis [39] & 2010 & 4 & - & - \\
Gingold [36] & 2014 & 15 & 60 & 40 \\
Kaminski [38] & 2017 & 23 & 48 & 52 \\
\hline
\end{tabular}

Table 3. Results with fistula plugs

\begin{tabular}{lcrll}
\hline First author [ref.] & Year & $n$ & $\begin{array}{l}\text { Healing, } \\
\%\end{array}$ & $\begin{array}{l}\text { Recurrence, } \\
\%\end{array}$ \\
\hline Champagne [41] & 2006 & 20 & 80 & 20 \\
Ky [42] & 2008 & 14 & 28 & 72 \\
Schwandner [43] & 2009 & 9 & 77 & 23 \\
Ellis [39] & 2010 & 12 & 66 & 34 \\
Herold [44] & 2016 & 4 & 25 & 75 \\
Cintron [45] & 2013 & 8 & 50 & 50 \\
\hline
\end{tabular}

Table 4. Results with fistulectomy with primary sphincter reconstruction

\begin{tabular}{lcccl}
\hline First author [ref.] & Year & $n$ & Healing, \% & Recurrence, \% \\
\hline Herold [46] & 2009 & 10 & 86 & 14 \\
Seyfried [3] & 2018 & 24 & $>85$ & $?$ \\
\hline
\end{tabular}

onstrated the first results of the VAAFT technique in PFCD. The aim of this prospective study was to analyze the feasibility and short-term efficacy of the VAAFT technique combined with transrectal advancement flap repair for the closure of complex fistulas in CD. Additional side tracts not detected preoperatively could be identified in $64 \%(7 / 11)$ of the patients. The follow-up was too short to provide definite healing rates. However, after a mean follow-up of 9 months, the success rate was $82 \%$ (9/11). In addition to the high costs of this procedure, the long-term results should be awaited. As in other studies, significantly worse cure rates can be expected over the long term. 


\section{Fistula Plugs}

There are two types of plugs that are commonly used in perianal fistulas. The bioabsorbable plug (Surgisis; Cook Surgical, Bloomington, IN, USA) is a xenograft made of lyophilized porcine intestinal submucosa. Its advantages include resistance to infections, absence of foreign-body reaction, and allowance for the repopulation of cells and tissues from the patient in a period of approximately 90 days [41]. The other available device is the synthetic plug (GORE Bio-A; W.L. Gore and Associates, Flagstaff, AZ, USA), which is composed by polyglycolic acid and trimethylene carbonate, two absorbable synthetic materials placed into the fistula tracks and fixated to the internal openings [27]. A recent meta-analysis reviewed the literature for the use of fistula plugs versus flap procedures in cryptoglandular fistulas. The authors revealed that the flap procedures had superiority over the plug in terms of healing and recurrence rates after pooling of RCTs with long-term follow-up. There were no significant differences in fistula complications between the procedures. In all studies, the healing rate and recurrence are between $20-80 \%$. The GORE plug has since been taken off the market.

The literature on PFCD is summarized in Table 3.

\section{Fistulectomy with Primary Sphincter Reconstruction}

In recent years, a direct repair (primary reconstruction) in distal fistulas was investigated and shows excellent results. There is no prospective trial including this technique in PFCD. However, retrospective studies could demonstrate promising results $[3,33,46]$ (Table 4).

\section{Conclusion}

Fistulas remain one of the major unmet needs in the treatment of $\mathrm{CD}$ patients. To date, only a limited number of effective therapies have been established. Most of the evidence on the following treatment options is derived from subgroup analyses or insufficiently defined second- ary outcome measures. As a consequence, any interpretation of the effectiveness of agents (above all comparative statements) have to be made with great caution. Longterm follow-up demonstrates that recurrence rates after the repair of complex fistulas for CD are high and continuously increase over time [47]. The dogma of surgery being but the last resort for anal CD needs to be revised. A strategy combining optimal medical therapy and sphincter-sparing surgery may successfully treat anal manifestations of $\mathrm{CD}$ and avoid progress without causing relevant functional impairment.

As mentioned above, it is not the singular surgical or medicinal measure that is effective in the therapy of PFCD. The best approach is a multimodal therapy concept in cooperation with an experienced gastroenterologist and experienced coloproctological surgeon. Through a combination of promising approaches in both disciplines, significant improvements in the therapy of PFCD can be achieved. Furthermore, a precise definition of fistula healing as opposed to asymptomatic fistula should be defined for the interpretation of future and existing literature.

\section{Disclosure Statement}

The authors declare that they have no conflicts of interest to disclose.

\section{Author Contributions}

S. Seyfried and A. Herold acquired and analyzed the data.

Both authors interpreted the data, revised the article for important intellectual content, and gave final approval of the version to be published.

\section{Funding Sources}

There was no funding available.

\section{References}

1 Hellers G, Bergstrand O, Ewerth S, Holmström B. Occurrence and outcome after primary treatment of anal fistulae in Crohn's disease. Gut. 1980 Jun;21(6):525-7.

2 de Groof EJ, Sahami S, Lucas C, Ponsioen CY, Bemelman WA, Buskens CJ. Treatment of perianal fistula in Crohn's disease: a systematic review and meta-analysis comparing seton drainage and anti-tumour necrosis factor treatment. Colorectal Dis. 2016 Jul;18(7):667-75.

3 Seyfried S, Bussen D, Joos A, Galata C, Weiss C, Herold A. Fistulectomy with primary sphincter reconstruction. Int J Colorectal Dis. 2018 Jul;33(7):911-8.
4 Gecse KB, Bemelman W, Kamm MA, Stoker J, Khanna R, Ng SC, et al.; World Gastroenterology Organization, International Organisation for Inflammatory Bowel Diseases IOIBD, European Society of Coloproctology and Robarts Clinical Trials; World Gastroenterology Organization International Organisation for Inflammatory Bowel Diseases IOIBD European Society of Coloproctology and Robarts Clinical Trials. A global consensus on the classification, diagnosis and multidisciplinary treatment of perianal fistulising Crohn's disease. Gut. 2014 Sep;63(9):138192.
5 Molendijk I, Bonsing BA, Roelofs $\mathrm{H}$, Peeters KC, Wasser MN, Dijkstra G, et al. Allogeneic Bone Marrow-Derived Mesenchymal Stromal Cells Promote Healing of Refractory Perianal Fistulas in Patients With Crohn's Disease. Gastroenterology. 2015 Oct;149(4):91827.e6.

6 Kotze PG, Shen B, Lightner A, Yamamoto T, Spinelli A, Ghosh S, et al. Modern management of perianal fistulas in Crohn's disease: future directions. Gut. 2018 Jun;67(6):118194. 
7 Galata C, Hirsch D, Reindl W, Post S, Kienle $\mathrm{P}$, Boutros $\mathrm{M}$, et al. Clinical and Histopathologic Features of Colorectal Adenocarcinoma in Crohn's Disease. J Clin Gastroenterol. 2018 Aug;52(7):635-40.

8 Hirsch D, Wangsa D, Zhu YJ, Hu Y, Edelman DC, Meltzer PS, et al. Dynamics of genome alterations in Crohn's disease-associated colorectal carcinogenesis. Clin Cancer Res. 2018 Oct;24(20):4997-5011.

9 Thia KT, Mahadevan U, Feagan BG, Wong C, Cockeram A, Bitton A, et al. Ciprofloxacin or Metronidazole for the Treatment of Periana Fistulas in Patients with Crohn's Disease: A Randomized, Double-Blind, Placebo-Controlled Pilot Study. Inflamm Bowel Dis; 2009 Jan;15(1):17-24.

10 Scharl M, Rogler G, Biedermann L. Fistulizing Crohn's Disease. Clin Transl Gastroenterol. 2017 Jul;8(7):e106.

11 Lee MJ, Heywood N, Sagar PM, Brown SR, Fearnhead NS; pCD Collaborators. Surgical management of fistulating perianal Crohn's disease: a UK survey. Colorectal Dis. 2017 Mar;19(3):266-73.

12 Dewint P, Hansen BE, Verhey E, Oldenburg B, Hommes DW, Pierik M, et al. Adalimumab combined with ciprofloxacin is superior to adalimumab monotherapy in perianal fistula closure in Crohn's disease: a randomised, double-blind, placebo controlled trial (ADAFI). Gut. 2014 Feb;63(2):292-9.

13 Tozer P, Borowski DW, Gupta A, Yassin N, Phillips R, Hart A. Managing perianal Crohn's fistula in the anti-TNFa era. Tech Coloproctol. 2015 Nov;19(11):673-8.

14 Pomié C, Blasco-Baque V, Klopp P, Nicolas S, Waget $\mathrm{A}$, Loubières $\mathrm{P}$, et al. Triggering the adaptive immune system with commensal gut bacteria protects against insulin resistance and dysglycemia. Mol Metab. 2016 Mar;5(6): 392-403.

15 Present DH, Rutgeerts P, Targan S, Hanauer SB, Mayer L, van Hogezand RA, et al. Infliximab for the treatment of fistulas in patients with Crohn's disease. N Engl J Med. 1999 May;340(18):1398-405.

16 Sands BE, Anderson FH, Bernstein CN, Chey WY, Feagan BG, Fedorak RN, et al. Infliximab maintenance therapy for fistulizing Crohn's disease. N Engl J Med. 2004 Feb;350(9):87685 .

17 Colombel JF, Schwartz DA, Sandborn WJ Kamm MA, D'Haens G, Rutgeerts P, et al. Adalimumab for the treatment of fistulas in patients with Crohn's disease. Gut. 2009 Jul 58(7):940-8.

18 Poggioli G, Laureti S, Pierangeli F, Rizzello F, Ugolini F, Gionchetti P, et al. Local injection of Infliximab for the treatment of perianal Crohn's disease. Dis Colon Rectum. 2005 Apr;48(4):768-74.

19 Asteria CR, Ficari F, Bagnoli S, Milla M, Tonelli F. Treatment of perianal fistulas in Crohn's disease by local injection of antibody to TNF- $\alpha$ accounts for a favourable clinical response in selected cases: a pilot study. Scand J Gastroenterol. 2006 Sep;41(9):1064-72.

20 Garcia-Olmo D, Herreros D, Pascual I, Pascual JA, Del-Valle E, Zorrilla J, et al. Expand- ed adipose-derived stem cells for the treatment of complex perianal fistula: a phase II clinical trial. Dis Colon Rectum. 2009 Jan; 52(1):79-86.

21 Ciccocioppo R, Bernardo ME, Sgarella A, Maccario R, Avanzini MA, Ubezio C, et al. Autologous bone marrow-derived mesenchymal stromal cells in the treatment of fistulising Crohn's disease. Gut. 2011 Jun;60(6):78898.

22 Panés J, García-Olmo D, Van Assche G, Colombel JF, Reinisch W, Baumgart DC, et al.; ADMIRE CD Study Group Collaborators. Expanded allogeneic adipose-derived mesenchymal stem cells (Cx601) for complex perianal fistulas in Crohn's disease: a phase 3 randomised, double-blind controlled trial. Lancet. 2016 Sep;388(10051):1281-90.

23 Lee JB, Yoon SG, Park KJ, Lee KY, Kim DD, Yoon SN, et al.; Korean IBD Study Group. The clinical features and predictive risk factors for reoperation in patients with Perianal Crohn diseases; A multi-center study of a Korean inflammatory bowel disease study group. Ann Coloproctol. 2015 Oct;31(5): 176-81.

24 O'Riordan JM, Datta I, Johnston C, Baxter NN. A systematic review of the anal fistula plug for patients with Crohn's and nonCrohn's related fistula-in-ano. Dis Colon Rectum. 2012 Mar;55(3):351-8.

25 Hyder SA, Travis SP, Jewell DP, McC Mortensen NJ, George BD. Fistulating anal Crohn's disease: results of combined surgical and infliximab treatment. Dis Colon Rectum. 2006 Dec;49(12):1837-41.

26 Thornton M, Solomon MJ. Long-term indwelling seton for complex anal fistulas in Crohn's disease. Dis Colon Rectum. 2005 Mar;48(3):459-63.

27 Ommer A, Herold A, Berg E, Fürst A, Sailer M, Schiedeck T; German Society for General and Visceral Surgery. Cryptoglandular anal fistulas. Dtsch Arztebl Int. 2011 Oct;108(42): 707-13.

28 Joo JS, Weiss EG, Nogueras JJ, Wexner SD. Endorectal advancement flap in perianal Crohn's disease. Am Surg. 1998 Feb;64(2): 147-50.

29 Makowiec F, Jehle EC, Becker HD, Starlinger M. Clinical course after transanal advancement flap repair of perianal fistula in patients with Crohn's disease. Br J Surg. 1995 May; 82(5):603-6.

30 Athanasiadis S, Nafe M, Köhler A. [Transanal rectal advancement flap versus mucosa flap with internal suture in management of complicated fistulas of the anorectum]. Langenbecks Arch Chir. 1995;380(1):31-6.

31 Sonoda T, Hull T, Piedmonte MR, Fazio VW. Outcomes of primary repair of anorectal and rectovaginal fistulas using the endorectal advancement flap. Dis Colon Rectum. 2002 Dec; 45(12):1622-8

32 Mizrahi N, Wexner SD, Zmora O, Da Silva G, Efron J, Weiss EG, et al. Endorectal advancement flap: are there predictors of failure? Dis Colon Rectum. 2002 Dec;45(12):1616-21.

33 Joos AK, Palma P, Jonescheit JO, Hasenberg T, Herold A. Enteral vs parenteral nutrition in reconstructive anal surgery-a prospectiverandomized trial. Colorectal Dis. $2008 \mathrm{Jul}$ 10(6):605-9.

34 van Koperen PJ, Safiruddin F, Bemelman WA, Slors JF. Outcome of surgical treatment for fistula in ano in Crohn's disease. Br J Surg. 2009 Jun;96(6):675-9.

35 Abcarian AM. Ligation of intersphincteric fistula tract (LIFT). In: Abcarian $\mathrm{H}$, editor. Anal Fistula. New York: Springer;2014. p. 115-119.

36 Gingold DS, Murrell ZA, Fleshner PR. A prospective evaluation of the ligation of the intersphincteric tract procedure for complex anal fistula in patients with Crohn's disease. Ann Surg. 2014 Dec;260(6):1057-61.

37 Sirany AM, Nygaard RM, Morken JJ. The ligation of the intersphincteric fistula tract procedure for anal fistula: a mixed bag of results. Dis Colon Rectum. 2015 Jun;58(6):604-12.

38 Kamiński JP, Zaghiyan K, Fleshner P. Increasing experience of ligation of the intersphincteric fistula tract for patients with Crohn's disease: what have we learned? Colorectal Dis. 2017 Aug;19(8):750-5.

39 Ellis CN. Outcomes with the use of bioprosthetic grafts to reinforce the ligation of the intersphincteric fistula tract (BioLIFT procedure) for the management of complex anal fistulas. Dis Colon Rectum. 2010 Oct;53(10): 1361-4.

40 Schwandner O. Video-assisted anal fistula treatment (VAAFT) combined with advancement flap repair in Crohn's disease. Tech Coloproctol. 2013 Apr;17(2):221-5.

41 Champagne BJ, O'Connor LM, Ferguson M, Orangio GR, Schertzer ME, Armstrong DN. Efficacy of anal fistula plug in closure of cryptoglandular fistulas: long-term follow-up. Dis Colon Rectum. 2006 Dec;49(12):1817-21.

42 Ky AJ, Sylla P, Steinhagen R, Steinhagen E, Khaitov S, Ly EK. Collagen fistula plug for the treatment of anal fistulas. Dis Colon Rectum. 2008 Jun;51(6):838-43.

43 Schwandner T, Roblick MH, Kierer W, Brom A, Padberg W, Hirschburger M. Surgical treatment of complex anal fistulas with the anal fistula plug: a prospective, multicenter study. Dis Colon Rectum. 2009 Sep;52(9): 1578-83.

44 Herold A, Ommer A, Fürst A, Pakravan F, Hahnloser D, Strittmatter B, et al. Results of the Gore Bio-A fistula plug implantation in the treatment of anal fistula: a multicentre study. Tech Coloproctol. 2016 Aug;20(8): 585-90.

45 Cintron JR, Abcarian H, Chaudhry V, Singer M, Hunt S, Birnbaum E, et al. Treatment of fistula-in-ano using a porcine small intestinal submucosa anal fistula plug. Tech Coloproctol. 2013 Apr;17(2):187-91.

46 Herold A, Joos A, Hellmann U, Bussen D. Treatment of high anal fistula: is fistulectomy with primary sphincter repair an option? Color Dis. 2009; $11: 15$

47 Löffler T, Welsch T, Mühl S, Hinz U, Schmidt J, Kienle P. Long-term success rate after surgical treatment of anorectal and rectovaginal fistulas in Crohn's disease. Int J Colorectal Dis. 2009 May;24(5):521-6. 